\title{
PROMOTING STUDENTS' CONFIDENCE THROUGH VIDEO PROJECT-BASED LEARNING
}

\author{
Via Nandiana ${ }^{1}$, Alan Jaelani ${ }^{2}$, Nurul Afiyattena ${ }^{3}$ \\ ${ }^{1 \& 2}$ Universitas Ibn Khaldun, ${ }^{3}$ STKIP La Tansha Mashiro \\ 11vnandiana @ gmail.com, ${ }^{2}$ alan.jaelani@uika-bogor.ac.id, ${ }^{3}$ nurulfiya1991@ gmail.com
}

\begin{abstract}
Students required confidence in order to use language they are learning, yet selfconfidence remain a challenge for them in language learning. This research examined Video Project-Based Learning (VPBL) as a method in educational process of delivering knowledge and skills. In this study, the researchers focused on students' perception on the use of projectbased learning using video as a method to promote students' confidence in learning English. The study was conducted at the fifth semester of 2019-2020 academic year in English Education Department of a university in Bogor. The data was collected by qualitative approach with openended questionnaire and semi-structed interview for ten students as the respondents. This research found that the use of VPBL make learning process efficient and practical, increased students' confidence in speaking skills with their own understanding and developed their creativity with the lesson. This research suggested taking a broader view of students' selfconfidence as the implication of video project-based learning in individual project.
\end{abstract}

Keywords: Students' perception, confidence, understanding, Video Project-Based Learning.

\section{INTRODUCTION}

Students should be skilled with one of the required skills in English that is communication. However, according to Rumiyati \& Seftika (2018) in their research revealed that various circumstances, such as speaking in front of the class, being called on by the teachers, unfavourable assessment by the teacher, being concerned about grammatical problems, mispronunciation, and being mocked by others, made students uneasy while speaking English. The impacts of communication anxiety are intimately related to the student's attitude, feel blank, confused, and unsure of what they would transmit. Self-confidence is crucial in speaking English because they need confidence to give a response without thinking about mistake in the practice of speaking English (Deswarni STAI Hubbulwathan Duri, 2017). Speaking is a production skill that incorporates fluency as one of its components (Jaelani \& Utami, 2020). According to Kelly in Deswarni (2017) the required ability to represent performance in such situation is the primary reason that someone has confidence in certain conditions. However, Chiert (2004:14) asserted that observation and intuition are able to enhance self-confidence and it can growth further. Student with good confidence to speak out loud without hesitancy can promote good relations with friends, and look at the people rather than look at the other way. Songsiri (2007) enhancing self-confidence in English communication is influenced by the teaching learning technique, the use of reputable sources, and the completion of the assignment at a convenient time. Video Project-Based Learning (VPBL) is a reliable source that is often employed in the teaching learning process nowadays. With this method, according to Howard in Shin (2018), students can complete the tasks by using a project-based learning teaching method. Baillie and Fitzgerald (2000) show that project-based learning may help to increase contribution and accountability, problem solving, public speaking, inventive and critical thinking, and selfconfidence. Shin (2018) confirmed in the research that project-based learning is good at 
motivating and increasing student engagement as well as encouraging students to be more active in their studies. Ngereja et al., (2020) also proved that project-based learning improves students' learning processes and demonstrates that the study combines real practise, which encourages competitiveness.

Empowering learners to learn was described as convincing them to take an interest in the exercises. By making exercises simpler for them, they accept that they will actually want to talk, on the off chance that they want to talk, empowering learners to accomplish their objectives, identifying with their disappointment while they were partaking in the exercises and lauding them when they prevailed in their language learning, particularly in communication. "The teacher is one of the main factors to promote students' confidence in language learning" (Songsiri, 2007). According to (Aryana, 2010 \& Al-Hebaish (2012) the most difficult task in language education is building learners' oral communication abilities. Despite engaging in various communicative activities is the most effective approach to help students speak the language effectively, proficiency in the L2 may not be sufficient. Literature has shown that there is a link between overall self-confidence and academic success. It is a contentious connection, with contradictory findings from various research. A substantial number of studies has found a link between self-confidence and language course grades. Similarly, because of strong selfconfidence fosters learners' desire to communicate and aids in language competence, it may result in academic achievement. The relationship between self-confidence and academic success is influential. Academic success rises when self-confidence rises, however it will be different when students have a low sense of self-confidence.

The previous study said that Project-based learning focuses on meaningful action in which participants engage in a hard and inspiring project to learn in a realistic, fascinating, and relevant manner. It additionally stresses the arranged learning and apprenticeship which manages genuine issues. Open ended generative errands are supported in which there is certainly not a recommended approach and that the students produce their own inquiries, plans and objectives. Shared dynamic and critical thinking is vital as groups work on projects in which they talk about, counsel, team up and issue tackle to make an item. This is also adaptive likewise changes the job of the teacher to an intellectual mentor who models, mentors, directs and empowers autonomy in objective setting and dynamic and advances reflection (Howard in Hung et al., 2004). Project-based learning is characterized as a complicated assignment that needs students to engage in design, problem solving, decision making, or investigative activities in order to answer tough questions or solve issues. It enables students to work independently for lengthy periods of time, resulting in realistic goods and presentations (Lee, 2012).

According to Miller et al., (2012) PBL is valuable for language students for an assortment of reasons:

- It coordinates the utilization of the four language abilities;

- Students can utilize an assortment of abilities other than language skills to impart (drawings, models, photographs and etc);

- It permits students who are solid in one region (language, technical, management) however feeble in others to add to an activity;

- It empowers participation between students;

- Students become more independent of their instructors and assume liability for their own learning;

- It makes genuine connections with students' encounters inside and outside of the study hall. Students' speaking skills and self-confidence improved considerably as a result of project-based learning (Jaya et al., 2019). Students' self-confidence had an impact on their learning in spaces 
of learners' investment, goal-setting, increasing interest in the class, reducing anxiety, being at ease with their teachers and classmates, and giving their thoughts about teachings in class (Akbari \& Sahibzada, 2020). Considering the previous research, how using video project-based learning can influence the English learners to be confidence, the aim of this research is to know students' perception on the use of Video Project-Based Learning, students' confidence using VPBL and Students' understanding on materials using VPBL.

\section{RESEARCH METHODOLOGHY}

This study used qualitative research design. The researchers used case study method. Case studies are an effective tool for research and education that focuses on the transfer from theory to practise and it is one of several ways of doing research, that can be used in many situations. According to Yin, (2003, p. 13) "a case study is an empirical inquiry that investigates a contemporary phenomenon within its real-life context, especially when the boundaries between phenomenon and context are not clearly evident."

The researchers used rating scale of Likert in getting information from participant. According to Likert, R. (1932) Likert scale is a psychometric response scale primarily used in questionnaires to obtain participant preferences or degree of agreement with a statement or set of statements. Respondents are asked to indicate their level of agreement with a given statement by way of an ordinal scale of five-point scale e.g., strongly agree, agree, neutral, disagree, strongly disagree.

The participants of this study were ten students in fifth semesters of English Education Department in a university in Bogor. The data were obtained from the courses that used video project-based learning method. The research chose only ten participants from 29 students to represent the other students and to keep the scope under control. There were two kind of data that were analysed from the students: students' confidence and the use of video project-based learning. The questionnaire was adapted from Poonpon (2011). An online (google form) and a semi-structured interview were used to collect the data. Students were permitted to respond in their native

\section{language}

(Indonesian language) in order to aid them in expressing their thoughts in answer to the questions and to prevent a language barrier in

communicating a message. Students' responses to the questionnaire and interview were translated into English.

\section{RESULTS AND DISCUSSIONS}

\section{Students' Perception on Learning English Using VPBL}

Diagram. "Learning English with video project-based learning is really efficient and practical." (Questionnaire)

The respondents asserted that video project-based learning can facilitate processing information faster, retain knowledge and remember it accurately, encourage students to apply and develop 
their creativity in learning. This method is quite effective for classroom learning in giving assignments to students, for example, making presentations via videos that can be done individually or in groups, then uploaded on Youtube, in order that learning process can be accessed at any time by students. VPBL really helps the learning process because the learning system is done via online; flexible for both students and teachers. Students also have time to prepare their great project in doing assignments. Additionally, there are $40 \%$ of the respondents agree with video project-based learning make learning processes efficient and practically and $30 \%$ strongly agree with the statements, only $10 \%$ disagree of the statement in the questionnaire. This finding is similar with Dhundi Raj Giri, (2016) that project-based learning is one of the most efficient teaching techniques in terms of practicality, originality, student involvement, and the use of a diverse range of learning resources, in which students actively participate in the learning process through hands-on activities tailored to their needs, interests, and topic.

\section{Students' Confidence in Using VPBL in Language Learning}

The results from the open-ended questionnaire showed that $60 \%$ respondents assumed VPBL promotes their confidences.
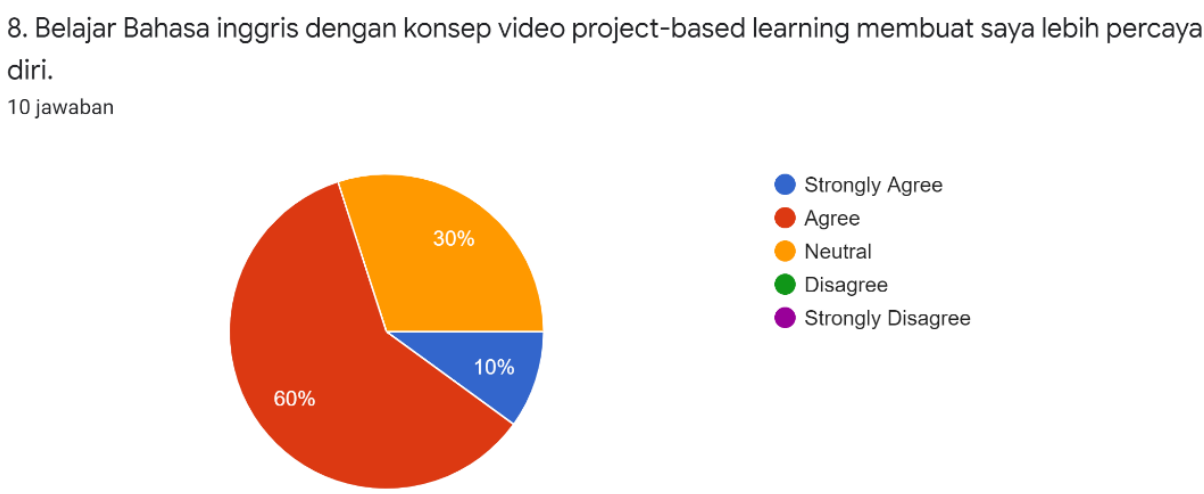

Diagram. "Learning English with the concept of video project-based learning made me more confident." (Questionnaire)

In addition, $50 \%$ respondents agree that they are more confident to do a task such as presentation as the implementation of VPBL.

Diagram. "Performing a learning presentation in English with video project-based learning method made me more confident." (Questionnaire) 

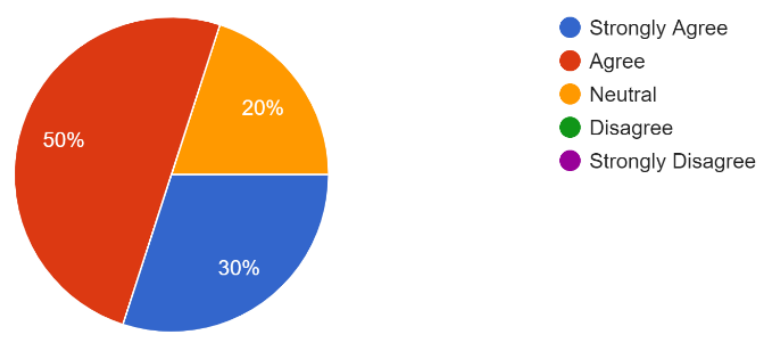
almost $90 \%$ of the respondents prefer working in pairs or group than using video project-based learning individualy.

Diagram. "Learning English based on video project-based learning in groups made me more confident." (Questionnaire)

The response was strengthened by respondents' opinion on the interviews. They responded that they were confident using VPBL in their ability to understand the materials, and became more confident to present something in front of their classmates and teacher. VPBL helps them

15. Belajar Bahasa Inggris berbasis video project-based learning secara kelompok membuat saya lebih percaya diri.

10 jawaban

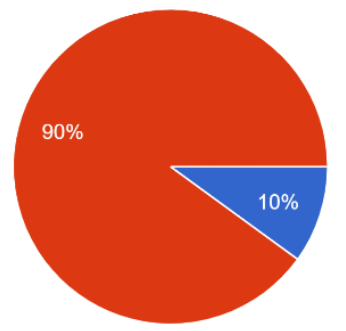

increase their confidence to start speaking up in front of friends, from those who were previously not confident in speaking English. By using videos, there are many creative ways of

knowledge that can be presented so that they can actually get better understanding on the lesson. The participants also argued that when the teacher gave an assignment to explain the material through video, they could immediately reflect on themselves and they could find out what shortcomings they had in doing the task and try to produce something better using VPBL. This finding is similar with Lubis (2020) that allowing students to complete the project increase their self-confidence since they have more opportunity to view a variety of sources and become more fluent in following the project's guidelines, and make their own.

\section{Students' Understanding of Materials Using VPBL}

Half of the respondents agrees with VPBL method that they can understand the material better and gain more knowledge in a shorter time. It was proved by $50 \%$ agree and $50 \%$ answered as neutral. 

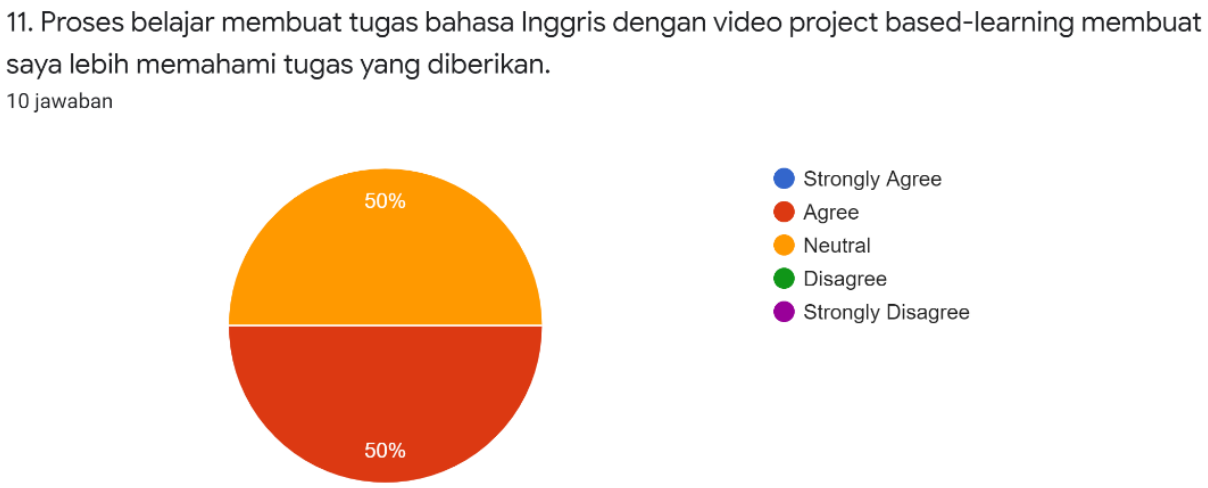

Diagram. "The process of learning to make an assignment with video project-based-learning made me understand the assignments better." (Questionnaire)

The use of VPBL can help them in understanding the material, such as when the explanation from the lecturer is not understandable. When the teacher adapted VPBL in the teaching process, they have an idea of the explanation of the materials and can re-watch the explanation of the learning material if they feel they do not understand.

\section{Diagram. \\ "Learning speaking skills in English with video project-based learning increases my creativity in learning." (Questionnaire)}

However, learning materials with VPBL must 10. Belajar speaking skill bahasa Inggris dengan video project-based learning meningkatkan kreativitas saya dalam belajar. 10 jawaban

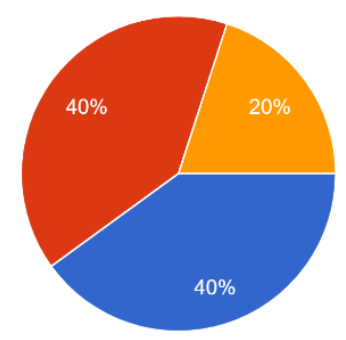

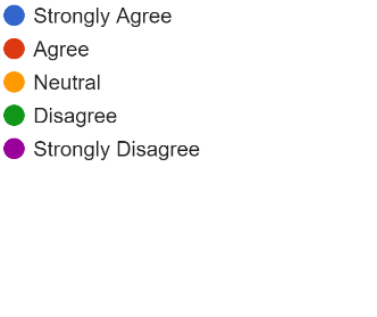
also be clear and informative to get them easily understand the lessons. VPBL also sharpens and increases students' creativity in learning English, $40 \%$ agree and $40 \%$ strongly agree, the rest respondents chose to answer neutral. This finding is in line with Salehudin et al., (2020) that during the learning process, creative learning allows students to conduct identification that is geared to creative and imaginative tasks, as well as strong self-confidence. The use of video project-based learning according with the participants of the interview, it made the range of material that can be accessed by students are wider, the activities that students carry out are also not monotonous, such as being creative through power point slides, using social media and et cetera. In addition, based on the interview VPBL can increase their speaking skills because they can deliver material with their own understanding and creativity. This finding also similar with Riswandi (2018) that, the use of PBL in the classroom can increase students' speaking abilities and motivation. The learners' performance in public speaking demonstrates this progress. Students can learn more quickly and feel more confident in dealing with the lesson since they rely not only on their speaking abilities but also on their understanding.

\section{CONCLUSION}


The results show that based on students' perception on the use of Video Project-Based Learning (VPBL) make learning processes efficient and practically. It can promote students' confidence whether the teacher taught them with VPBL method or when they have to do an assignment adapting VPBL. The students can be more confident in speaking English in front of their friends and teachers, such as delivering presentation in front of the class, although almost of them still prefer working in pairs than individually. However, this method is effective for learning and teaching process in giving lesson and assignments to the students. In addition, it can make students understand more, get prepared with the lessons and improve their creativity as they can make improvisation with the lesson through VPBL. The utilization of VPBL can help them in understanding the materials when the explanation from the teacher need repetition. When the teacher adjusted VPBL in the lesson, students have a thought of the material explanation and to express their creativity in doing a task with VPBL method. Furthermore, students' self-confidence as the implementation of video project-based learning in individually project should be taken into account.

\section{REFERENCES}

Akbari, O., \& Sahibzada, J. (2020). Students' Self-Confidence and Its Impacts on Their Learning Process. American International Journal of Social Science Research, 5(1), 1-15. https://doi.org/10.46281/aijssr.v5i1.462

Al-Hebaish, S. M. (2012). The correlation between general self-confidence and academic achievement in the oral presentation course. Theory and Practice in Language Studies, 2(1), 6065. https://doi.org/10.4304/tpls.2.1.60-65

Baillie, C. \& Fitzgerald, G. 2000. Motivation and attribution in engineering students. European Journal of Engineering Education, 25(2), 45-155.

Chiert, J \& Hunsberger, B. 2004. All You Need to Teach Series Drama: Learning Through Movement, Improvisation, Mine and Speech. Australia: Macmillan Education Aus.

Deswarni STAI Hubbulwathan Duri, D. (2017). The Use of Skit Technique to Increase Students' Self-Confidence in Speaking. Al-Ishlah: Jurnal Pendidikan, 9(2), 101-113.

Dhundi Raj Giri. (2016). Project-Based Learning as 21st Century Teaching Approach: A Study in Nepalese Private Schools. US-China Education Review A, 6(8). https://doi.org/10.17265/2161$623 x / 2016.08 .004$

Hung, V. H. K., Keppell, M., \& Jong, M. S. Y. (2004). Learners as producers: Using project-based learning to enhance meaningful learning through digital video production. Beyond the Comfort Zone Proceedings of the 21st ASCILITE Conference, 428-436.

Jaelani, Alan \& Utami, Imanda Rizkatria (2020). The Implementation of Just a Minute (JAM) Technique to Scaffold Students' Speaking Fluency: A Case Study. English Journal 14 (1), 1-15

Jaya, A., Hermansyah, H., \& Rosmiyati, E. (2019). The implementation of project-based learning in increasing speaking achievement and self-confidence. Indonesian Educational Administration and Leadership Journal (IDEAL), 1(1), 4-19.

Lee, A. K. (2012). Application of Project-Based Learning in Students' Engagement in Malaysian Studies and English Language. Journal of Interdisciplinary Research in Education (JIRE), 2(1), $37-46$. 
Likert, R. (1932). A technique for the measurement of attitudes. Archives of Psychology, 22 140, 55.

Lubis, N., Lubis, A., \& Purba, N. B. (n.d.). Project-Based Learning Collaborated with Digital Media for Indonesian Efl Learners' Self-Confidence and Communication Skill.

Miller, L., Hafner, C. A., \& Fun, C. N. K. (2012). Project-based learning in a technologically enhanced learning environment for second language learners: Students' perceptions. E-Learning and Digital Media, 9(2), 183-195. https://doi.org/10.2304/elea.2012.9.2.183

Ngereja, B., Hussein, B., \& Andersen, B. (2020). Does project-based learning (PBL) promote student learning? a performance evaluation. Education Sciences, 10(11), 1-15. https://doi.org/10.3390/educsci10110330

Poonpon, K. (2011). Enhancing English Skills through Project-Based Learning. The English Teacher, XL, 1-10.

Riswandi, D. (2018). The Implementation of Project-Based Learning to Improve Students' Speaking Skill. March International Journal of Language Teaching and Education (IJoLTe) Skill. International Journal of Language Teaching and Education, 2(1), 32-40. http://creativecommons.org/licenses/by/4.0/

Rumiyati, \& Seftika. (2018). Anxiety of Speaking English in English Foreign Language (Efl) Class. Journal of English Education E- Literature and Linguistics, 1(1), 46-61.

Salehudin, M., Sarimin, S., Manado, P. K., Yunus, M., Safiah, I., Sarimin, D. S., Harvie, R., \& Rondonuwu, S. (2020). Using Instagram to Support Creative Learning and Project Based Learning. International Journal of Advanced Science and Technology, 29(5), 4866-4876. https://www.researchgate.net/publication/343017746

Shin, M.-H. (2018). Effects of project-based learning on students' motivation and self-efficacy. English Teaching, 73(1), 95-115. https://doi.org/10.15858/engtea.73.1.201803.95

Songsiri, M. (2007). An Action Research Study of Promoting Students' Confidence in Speaking English. In Education and Human Development Victoria University (Issue March).

Yin, R. (2003). Case study research: Design and methods (3rd ed.). Thousand Oaks, CA: Sage. 